\title{
RECEIVED
}

APR 041990

OSTI

\section{Laboratory Testing of the In-Well Vapor-Stripping System}

T. J Gilmore

O. Francois

March 1996

Prepared for

the U.S. Department of Energy

Contract DE-AC06-76RLO 1830

Pacific Northwest National Laboratory Operated for the U.S. Department of Energy by Battelle 


\title{
DISCLAIMER
}

This report was prepared as an account of work sponsored by an agency of the United States Government. Neither the United States Government nor any agency thereof, nor Battelle Memorial Institute, nor any of their employees, makes any warranty, express or implied, or assumes any legal liability or responsibility for the accuracy, completeness, or. usefulness of any information, apparatus, product, or process disclosed, or represents that its use-would not infringe privately owned rights. Reference herein to any specific commercial product, process, or service by trade name, trademark, manufacturer, or otherwise does not necessarily constitute or imply its endorsement, recommendation, or favoring by the United States Government or any agency thereof, or Battelle Memorial Institute. The views and opinions of authors expressed herein do not necessarily state or reflect those of the United States Government-or any agency thereof.

\author{
PACIFIC NORTHWEST NATIONAL LABORATORY \\ operated by \\ BATTELLE \\ for the \\ UNITED STATES DEPARTMENT OF ENERGY \\ under Contract DE-ACO6-76RLO 1830 \\ Printed in the United States of America \\ Available to DOE and DOE contractors from the \\ Office of Scientific and Technical Information, P.0. Box 62, Oak Ridge, TN 37831; \\ prices available from (615) 576-8401.
}

Available to the public from the National Technical Information Service, U.S. Department of Commerce, 5285 Port Royal Rd.. Springfield, VA 22161 


\title{
Laboratory Testing of the In-Well Vapor-Stripping System
}

\author{
T. J Gilmore \\ O. Francois
}

March 1996

Prepared for

the U.S. Department of Energy

under Contract DE-AC06-76RLO 1830

Pacific Northwest National Laboratory

Richland, Washington 99352 


\section{Summary}

The in-well vapor-stripping system is a remediation technology designed to preferentially extract volatile organic compounds (VOCs) dissolved in groundwater by converting them to a vapor phase and treating the vapor. The concept was initially proposed by researchers at Stanford University and is currently under development through a collaboration between Stanford University and the U.S. Department of Energy's Pacific Northwest National Laboratory. ${ }^{(2)}$ Air-lift pumping is used to elevate and aerate groundwater within the well. The VOCs escaping the aerated water are drawn off and treated at the surface, while the treated water is allowed to infiltrate the vadose zone back to the water table. This simultaneous extraction of groundwater and the re-introduction of the water above the water table creates a circulation cell in the subsurface that sequentially removes the VOCs from the groundwater.

To verify the concept and design of the system, a series of laboratory tests were performed at the Hanford Site, Washington. The laboratory setup consisted of clear acrylic tubing that formed a 75-ft (22.9-m) column. The column was a full-scale replica of the proposed field demonstration of the in-well vapor-stripping demonstration planned at Edwards Air Force Base, California in the summer of 1995. The testing provided operating curves that relate air-flow rate and pressures with water-flow rates under varying system configurations. The results from this laboratory testing are being used to develop a physically-based air-lift pumping model. Laboratory results also indicated that, with the anticipated field demonstration configuration, the flow regime inside the pipe will be primarily in a slug-flow regime. The size of the openings in the bubble diffuser did not appear to have a significant effect on the final bubble size at the top of the column or on the flow regime. Stripping-efficiency tests were conducted using the chlorinated solvent 1,1,1-trichloroethane (TCA). Although some adsorption of the TCA onto the acrylic was measured, the system's stripping efficiency of TCA was greater than $50 \%$ per pass through the system using an air-to-water flow rate ratio of 7.5 to 1 . The air-to-water ratio has a significant effect on the stripping efficiency of the system and it is anticipated that the stripping efficiency can be greatly increased with higher air-to-water ratios.

(a) Pacific Northwest National Laboratory is operated for the U.S. Department of Energy by Battelle Memorial Institute. 



\section{Acknowledgments}

Contributors to the success of this laboratory experiment include Dr. Steve Gorelick and Mr. Mike Pinto, Stanford University; Dr. Kirk Cantrell, Dr. Lucia Liljegren, and Dr. Chuck Stewart of Pacific Northwest National Laboratory; Mr. Chris Wright of Hart-Crowser; Ms. Milagros Cintron of the University of Puerto Rico; Mr. John Davis, Mr. Mike Dahl, Mr. Blaine Hopkins, Mr. Jason Gunter, Mr. Steve Trent, and Mr. Jim Coates of Westinghouse Hanford Company. 



\section{Contents}

Summary $\ldots \ldots \ldots \ldots \ldots \ldots \ldots \ldots \ldots \ldots \ldots \ldots \ldots \ldots \ldots \ldots \ldots \ldots$ iii

Acknowledgments $\ldots \ldots \ldots \ldots \ldots \ldots \ldots \ldots \ldots \ldots \ldots \ldots \ldots \ldots \ldots$

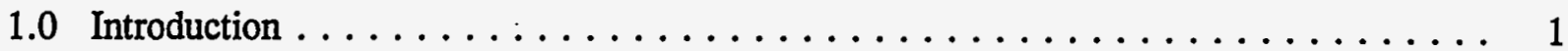

1.1 Process Description $\ldots \ldots \ldots \ldots \ldots \ldots \ldots \ldots \ldots \ldots \ldots \ldots \ldots \ldots \ldots \ldots \ldots$

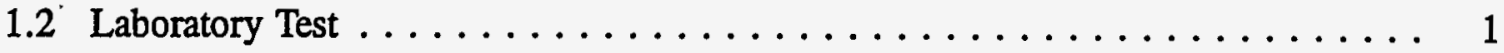

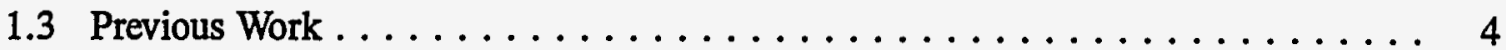

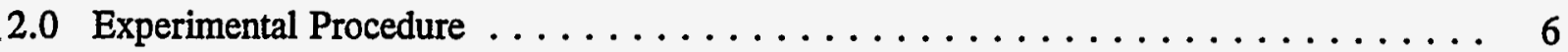

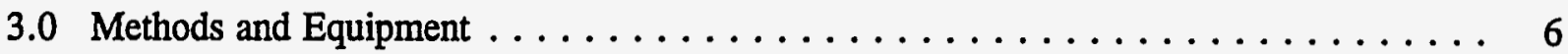

3.1 Measurement Instrumentation $\ldots \ldots \ldots \ldots \ldots \ldots \ldots \ldots$

4.0 Design of System Components $\ldots \ldots \ldots \ldots \ldots \ldots \ldots \ldots \ldots$

4.1 Down-Well Water-Flow Meter $\ldots \ldots \ldots \ldots \ldots \ldots \ldots \ldots \ldots \ldots$

4.1 .1 Resolution of Flow $\ldots \ldots \ldots \ldots \ldots \ldots \ldots \ldots \ldots \ldots$

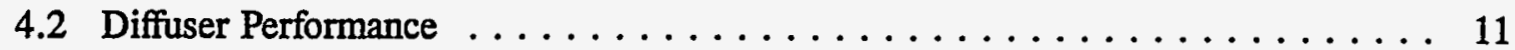

5.0 System Operating Parameters $\ldots \ldots \ldots \ldots \ldots \ldots \ldots \ldots \ldots \ldots$

5.1 Mass Transfer . . . . . . . . . . . . . . . . . . . 14

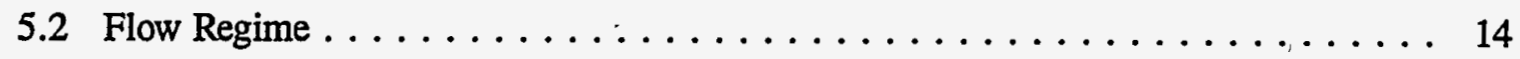

6.0 Miscellaneous Observations . . . . . . . . . . . . . . . . 16

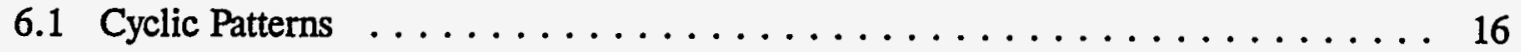

6.2 Air-to-Water Flow Rate Ratios and Air Holdup Calculations $\ldots \ldots \ldots \ldots \ldots$

6.3 Aeration of Water Returning to the Formation $\ldots \ldots \ldots \ldots \ldots$

6.4 Potential of Injecting Air into the Formation $\ldots \ldots \ldots \ldots \ldots \ldots$ 
6.5 Hydrometer Readings $\ldots \ldots \ldots \ldots \ldots \ldots \ldots \ldots \ldots \ldots \ldots$

6.6 Temperature Readings $\ldots \ldots \ldots \ldots \ldots \ldots \ldots \ldots \ldots \ldots \ldots \ldots$

7.0 Stripping-Efficiency Tests $\ldots \ldots \ldots \ldots \ldots \ldots \ldots \ldots \ldots \ldots \ldots \ldots \ldots$

7.1 Selection of Test Contaminant for Stripping Tests $\ldots \ldots \ldots \ldots \ldots \ldots \ldots$

8.0 Stripping Efficiency of TCA $\ldots \ldots \ldots \ldots \ldots \ldots \ldots \ldots \ldots \ldots \ldots \ldots \ldots \ldots \ldots \ldots \ldots$

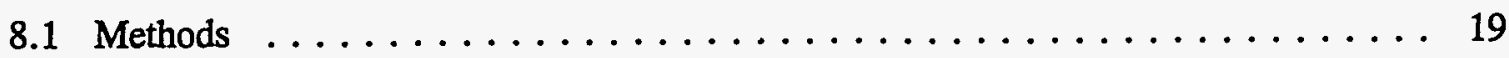

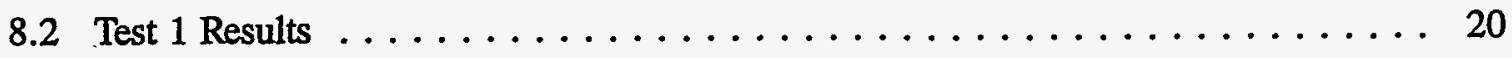

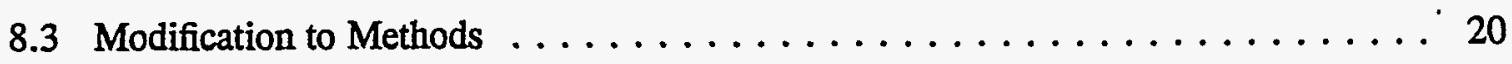

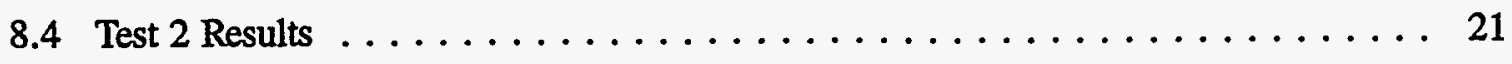

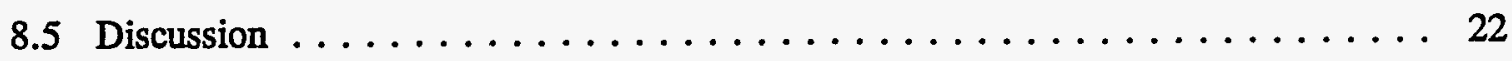

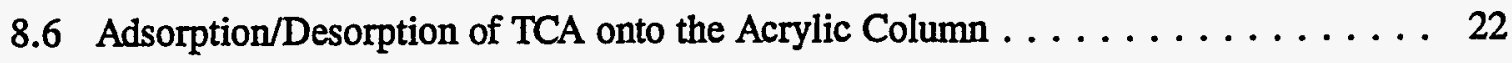

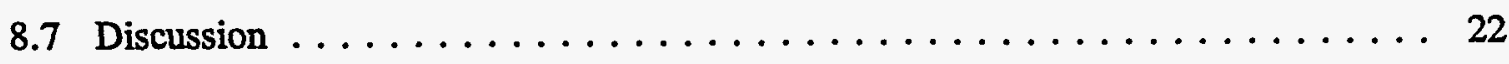

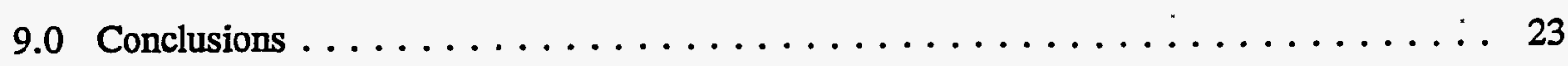

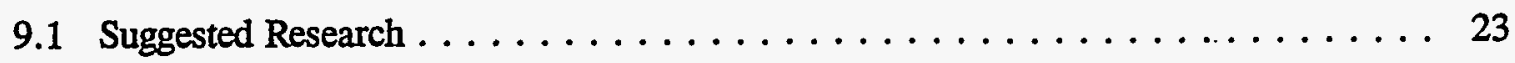

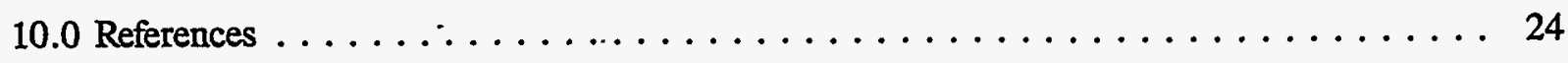




\section{Figures}

1 Conceptual Design for In-Well Vapor-Stripping System $\ldots \ldots \ldots \ldots \ldots$

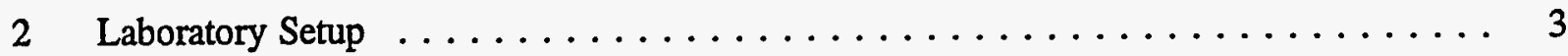

3 Photograph of Laboratory Stripping Column $\ldots \ldots \ldots \ldots \ldots \ldots \ldots$

4 Down-Well Water-Flow Meter (Weir) $\ldots \ldots \ldots \ldots \ldots \ldots \ldots \ldots$

5 Power Function Determination for Weir Calibration $\ldots \ldots \ldots \ldots \ldots \ldots$

6 Operating Curves Using a 400 -micron Sparger Element $\ldots \ldots \ldots \ldots \ldots \ldots \ldots$

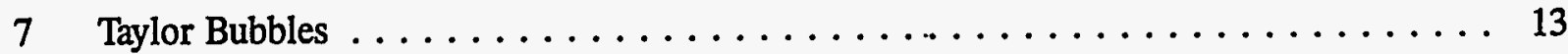

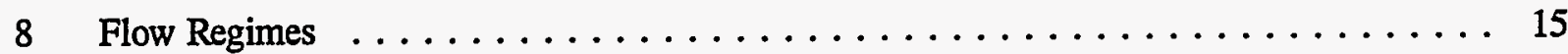

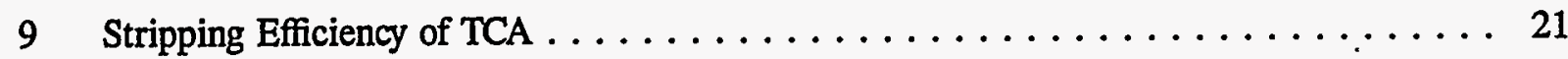

\section{Tables}

1 Characteristics of the Laboratory Vapor-Stripping System $\ldots \ldots \ldots \ldots \ldots$

2. Characteristics of Chlorinated Hydrocarbons . . . . . . . . . . . . 19

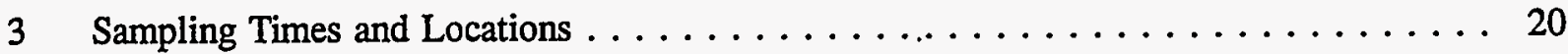





\subsection{Introduction}

The Volatile Organic Compounds-Arid Integrated Demonstration (VOC-Arid ID) was implemented by the U.S. Department of Energy's (DOE's) Office of Technology Development to develop and test new technologies for the remediation of organic chemicals in the subsurface. One of the technologies being tested under the VOC-Arid ID is the in-well vapor-stripping system. The in-well vapor-stripping concept was initially proposed by researchers. at Stanford University (Gvirtzman and Gorelick 1992) and is currently under development through a collaboration between workers at Stanford University and DOE's Pacific Northwest National Laboratory.

The project to demonstrate the in-well vapor-stripping technology is divided into three phases: 1) conceptual model and computer simulation, 2) laboratory testing, and 3) field demonstration. This report provides the methods and results of the laboratory testing in which a full-scale replica was constructed and tested above ground in a test facility located at DOE's Hanford Site, Washington. The system is a remediation technology designed to preferentially extract volatile organic compounds (VOCs) from contaminated groundwater by converting them to a vapor phase (Figure 1).

\subsection{Process Description}

In the field application, the in-well vapor-stripping system essentially creates an underground air stripper. Air-lift pumping is used to elevate and aerate groundwater inside the well. The VOCs escaping the aerated water are drawn off through the well and treated at the surface. The system is constructed as a well within a well--an inner well extends from the ground surface into the aquifer and is open to the aquifer at the zone of contamination; the outer well extends from the ground surface through the vadose zone and may terminate above the aquifer. Air is injected into the bottom of the inner well through a small-diameter $(\sim 1-$ in. $[\sim 2.5-\mathrm{cm}])$ air line. This injected air both aerates and lifts the water within the well. The aeration preferentially partitions the VOCs that are in the water into the vapor phase. The VOC vapors that are stripped out of the water are drawn to the surface for treatment.

The injected air into the well also lifts the water in the inner well until it hits a rubber flange that then directs the water into the annular space between the inner and outer well casings. The outer well casing has a screen through which the cleaned water reinfiltrates back into the sediments. The reinfiltrating water moves back down to the aquifer and some of the water is drawn back into the well through the lower screen for stripping in the well again. Eventually, the natural groundwater flow moves the treated water downgradient of the circulation cell while bringing more contaminated water into the circulation cell. The groundwater may make several passes through the stripping system before moving out of the zone of recirculation.

\subsection{Laboratory Test}

In essence, the laboratory setup is a full-scale replica of the proposed field demonstration. The laboratory apparatus is shown in Figure 2. The setup consists of two diameters of clear acrylic tubing, 

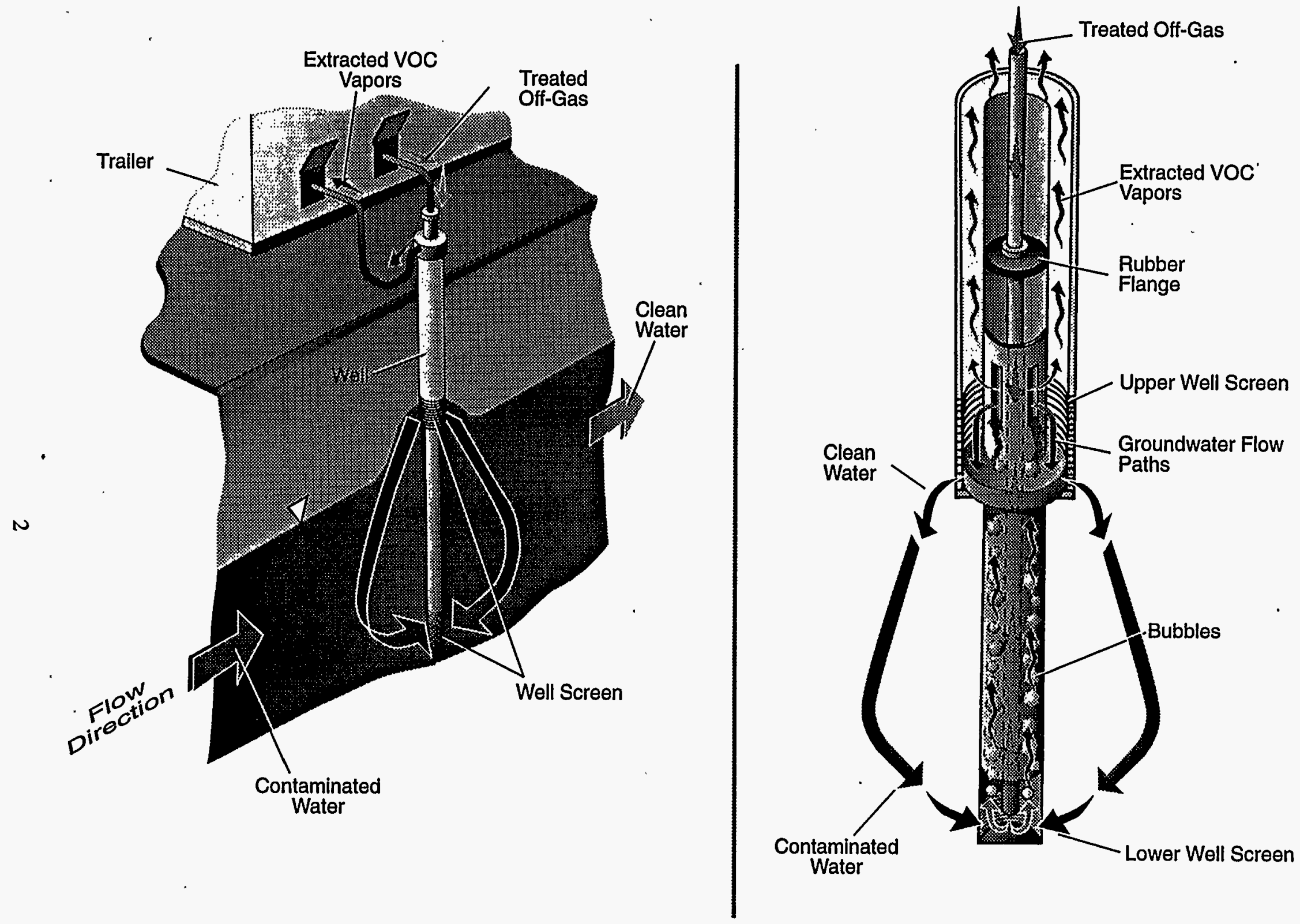

S9509006.1

Figure 1. Conceptual Design for In-Well Vapor-Stripping System 


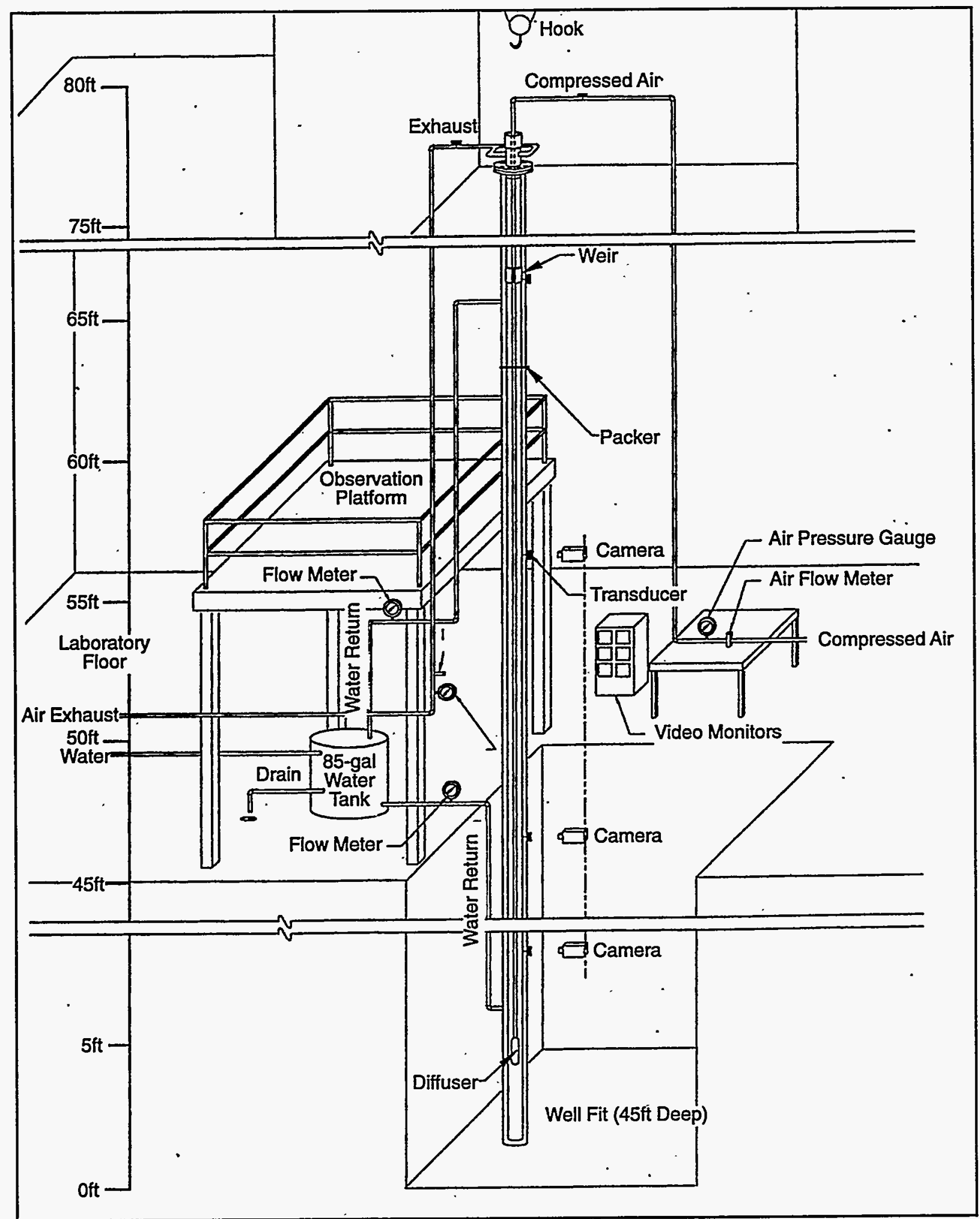

$\$ 9509006.2$

Figure 2. Laboratory Setup 
one inside the other, that form a column $75 \mathrm{ft}(22.9 \mathrm{~m})$ high. The setup was located in the 306E laboratory of the 300 Area within DOE's Hanford Site, Washington. The laboratory has a high bay ceiling and associated 45-ft $(13.7-\mathrm{m})$-deep pit, allowing for more than $85 \mathrm{ft}(25.9 \mathrm{~m})$ of clearance vertically. The designed height and diameter of the laboratory setup are the same dimensions expected in the field demonstration (Figure 3).

The laboratory testing provided an intermediate step between conceptual design and field application. The objectives of the laboratory tests were to 1) provide proof of principle, 2) determine optimum operating parameters of the system, 3) design and calibrate components of the system for deployment in the field, and 4) develop a predictive air-lift pumping model.

The laboratory testing provided the following results:

- developed operating curves that relate air-flow rate, air pressures, and water-flow rates under varying system configurations

- determined empirically the stripping efficiency of the system

- determined air-holdup ratios under different operating parameters

- tested effects of various diffusers on system performance

- calibrated a down-well water-flow-measuring device.

The results of the laboratory testing will be used to optimize the stripping efficiency of the system. Many of the parameters collected are intended for use in characterizing the mass-transfer performance. Ultimately, the results from this laboratory testing will be used to develop a computer simulator of the system. This computer simulator is currently under development at Stanford University and its development will be covered in a separate report. This report focuses on the methods and results of the laboratory testing.

\subsection{Previous Work}

Although the application and design of the in-well vapor-stripping system are unique, there is a large body of research on the concepts of partitioning VOCs into the vapor phase by aerating fluids in a vertical column. These above-ground bubble column reactors, or vapor-stripping columns, are used commonly in industrial processes to treat waste products. This laboratory experiment is very similar to studies of mass transfer in bubble columns, bubble coalescence, and mapping flow regimes. The field application of the in-well vapor-stripping system, however, will have the complicating effects of the geologic environment.

Papers in the literature that investigate the vertical upward flow patterns include Gilick and Kestin (1987), Calderbank et al. (1964), and Taitel et al. (1980). Several studies were devoted to the modeling of air-lift pumping systems: Zenz (1993), Richardson and Higson (1962), Shaw (1920), Husain and Spedding (1976), Alimonti and Galardini (1992), Clark and Dabolt (1986), and Reinemann et al. (1990). The two experiments that had conditions similar to this vapor-stripping system (i.e., 


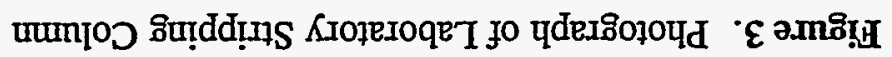

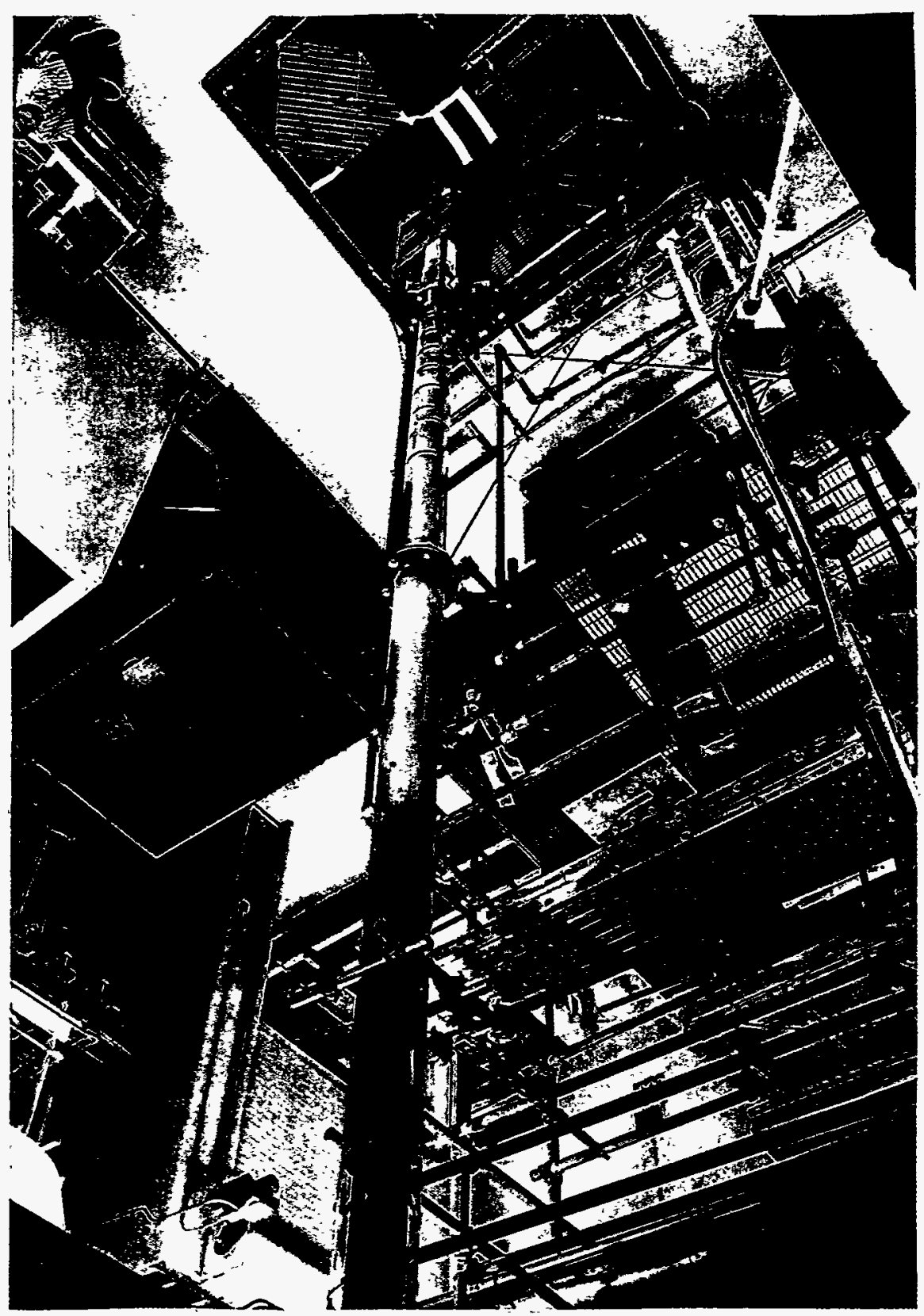


column height, diameter, maximum liquid, air velocities) were Clark and Dabolt (1986) and Alimonti and Galardini (1992). There are also a number of papers that investigate the aspects of mass transfer in bubble columns, including Miller (1993), Hsueh et al. (1991), Akita and Yoshida (1973), and Lehrer (1971).

\subsection{Experimental Procedure}

The principle of air-lift pumping is to inject air into a well, which in effect lightens the column of fluid contained in the well. Water will rise as a result of the difference in the weight of the air-water mixture inside the well compared to the weight of the water outside the well. In our laboratory study, air is injected into an inner well while maintaining a constant head outside, in an outer well. The key variables that were controlled in the experiments are the air-flow rate, $\mathrm{Q}_{\mathrm{G}}$; the water-pumping rate, $\mathrm{Q}_{\mathrm{L}}$; the submergence, $S$; and the lift, $L$. The submergence is the level at which air is injected below the water table, or in our experiments, the level maintained in the outer well. The lift is the height of water rise above the water table. The submergence ratio is a parameter commonly found in air-lift analysis and is defined as the ratio of the submergence to the total length, $\alpha=S$ over $1+S$, where $S$ is the submergence and 1 is the required lift above the static water level. The air-flow rate is measured through a flow meter that is placed before where the air enters the well; the water-pumping rate is controlled by an entrance valve and is measured by a flow meter at the inlet. The characteristics of the laboratory vapor-stripping system are given in Table 1.

The laboratory tests involved two sets of runs, based on the elevation of the air sparger ( 5 and $25 \mathrm{ft}$ $(1.5$ and $7.6 \mathrm{~m})$, respectively) above the bottom of the outer well. For a given sparger elevation, a range of air-flow rates was used, and specified submergence values were maintained. The corresponding water-flow rates were measured. For the first set of experiments, in which the sparger was $5 \mathrm{ft}(1.5 \mathrm{~m})$ off the bottom, 4 series of runs were made, characterized by a fixed submergence $(30,35$, 40 , and $45 \mathrm{ft}[9.1,10.7,12.2$, and $13.7 \mathrm{~m}])$. For the second set of runs, only 2 submergence values were considered (15 and $25 \mathrm{ft}$ [6.1 and $7.6 \mathrm{~m}]$ ). In each run, the water-flow rate varied from 5 to $70 \mathrm{gal} / \mathrm{min}$ and was measured within $\pm 1 \mathrm{gal} / \mathrm{min}$. The lift was measured within $\pm 2 \mathrm{ft}( \pm 0.61 \mathrm{~m})$. The air-flow rate was measured within $\pm 3 \mathrm{sft}^{3} / \mathrm{min}$ ( $\pm 85 \mathrm{l} / \mathrm{min}$ ). Measurements of pressure were obtained through transducers placed along the inner well and the two-phase flow pattern was recorded on videotapes at different elevations.

\subsection{Methods and Equipment}

The setup consisted of two sizes of acrylic tubing, 6- and 10-in. (15.2- and 25.4-cm) dia., a 1-in. (2.5-cm)-dia. steel air-supply line, and an 85-gal holding tank with associated plumbing (see Figure 2). The 6-in. $(15.2-\mathrm{cm})$ tubing acted as the bubble column, air was injected into the tubing by the steel pipe, and the injected air both lifted and aerated the water inside the tubing. The outer 10-in. $(25.4-\mathrm{cm})$ tubing was separated into 2 sections by a metal plate at a height of $60 \mathrm{ft}(18.3 \mathrm{~m})$. The 
Table 1. Characteristics of the Laboratory Vapor-Stripping System

\begin{tabular}{||l|c|l||}
\hline \multicolumn{1}{|c|}{ Description } & \multicolumn{1}{|c|}{ Variable } & \multicolumn{1}{|c|}{ Values in Experiments } \\
\hline \hline Inside diameter of well & $\mathrm{d}_{\mathrm{i}}$ & $5.5 \mathrm{in} .(14.2 \mathrm{~cm})$ \\
\hline Outside diameter of well & $\mathrm{d}_{\mathrm{o}}$ & $1.3 \mathrm{in} .(3.3 \mathrm{~cm})$ \\
\hline Total inner-well length & $\mathrm{L}_{\mathrm{ppe}}$ & $70 \mathrm{ft}(21.3 \mathrm{~m})$ \\
\hline Elevation of diffuser off the bottom & $\mathrm{h}$ & 5 and $25 \mathrm{ft}(1.5$ and $7.6 \mathrm{~m})$ \\
\hline $\begin{array}{l}\text { Fixed submergence } \\
\text { w/h }=5 \mathrm{ft}(1.5 \mathrm{~m})\end{array}$ & $\mathrm{S}$ & $\begin{array}{l}30,35,40, \text { and } 45 \mathrm{ft} \\
(9.1,10.7,12.2, \text { and } 13.7 \mathrm{~m})\end{array}$ \\
w/h $=25 \mathrm{ft}(7.6 \mathrm{~m})$ & & 15 and $25 \mathrm{ft}(6.1$ and $9.1 \mathrm{~m})$ \\
\hline Lift & & $20,25,30$, and $35 \mathrm{ft}$ \\
w/h $=5 \mathrm{ft}(1.5 \mathrm{~m})$ & $\mathrm{L}$ & $(6.1,7.6$, and $10.7 \mathrm{~m})$ \\
w/h $=25 \mathrm{ft}(7.6 \mathrm{~m})$ & & 20 and $30 \mathrm{ft}(6.1$ and $9.1 \mathrm{~m})$ \\
\hline Water-flow rate & & 5 to $70 \mathrm{gal} / \mathrm{min}(0.7 \mathrm{to} 9.4 \mathrm{ft} / \mathrm{min})$ \\
\hline Gas-flow rate & $\mathrm{Q}_{\mathrm{L}}$ & $7 \mathrm{to} 38 \mathrm{sft} / \mathrm{min}(198$ to $1076 \mathrm{l} / \mathrm{min})$ \\
\hline
\end{tabular}

lower section of the annulus between the 6- and 10-in. (15.2- and 25.4-cm) tubing acted as a reservoir for the water in the system. The upper section of the 10 -in. $(25.4-\mathrm{cm})$ tubing above the steel plate was used to recirculate the water that was air lifted from inside the 6 -in. $(15.2-\mathrm{cm})$ tubing back into the 85-gal holding tank. The holding tank was used to maintain the level of water in the lower section of 10-in. (25.4-cm) tubing. See Figure 2.

The 6-in. (15.2-cm) tubing was suspended approximately $2 \mathrm{ft}(0.61 \mathrm{~m})$ off the bottom of the 10 -in. $(25.4-\mathrm{cm})$ casing to allow water to enter into the 6-in. $(15.2-\mathrm{cm})$ tubing from the 10 -in. $(25.4-\mathrm{cm})$ tubing. The 1-in. $(2.5-\mathrm{cm})$ steel air line was suspended approximately $5 \mathrm{ft}(1.5 \mathrm{~m})$ off the bottom of the 10 -in. $(25.4-\mathrm{cm})$ casing, or $3 \mathrm{ft}(0.9 \mathrm{~m})$ above the bottom of the 6-in. $(15.2-\mathrm{cm})$ tubing. The length of the air-injection line, however, could be adjusted to vary submergence depth of the sparging element.

Three different sparging elements were designed to fit on the end of the air line to create the bubbles. The spargers included 2 commercially available spargers that were cylinders $10 \mathrm{in} .(25.4 \mathrm{~cm})$ long and 2.25 in. $(5.7 \mathrm{~cm})$ in diameter. They were made of sintered stainless steel, with openings of 100 and 400 microns. The sparger elements were made by Mott Metallurgical Corporation. A third sparging element was constructed in the laboratory of the same dimensions but of a wire-mesh screen with openings of approximately $1.5 \mathrm{~mm}$.

A manifold at the top of the acrylic tubing was used to channel the exhausted air stream into the laboratory's vent system. The manifold was constructed in the laboratory of stainless steel and was designed to be used in the field demonstration (Figure 2). 


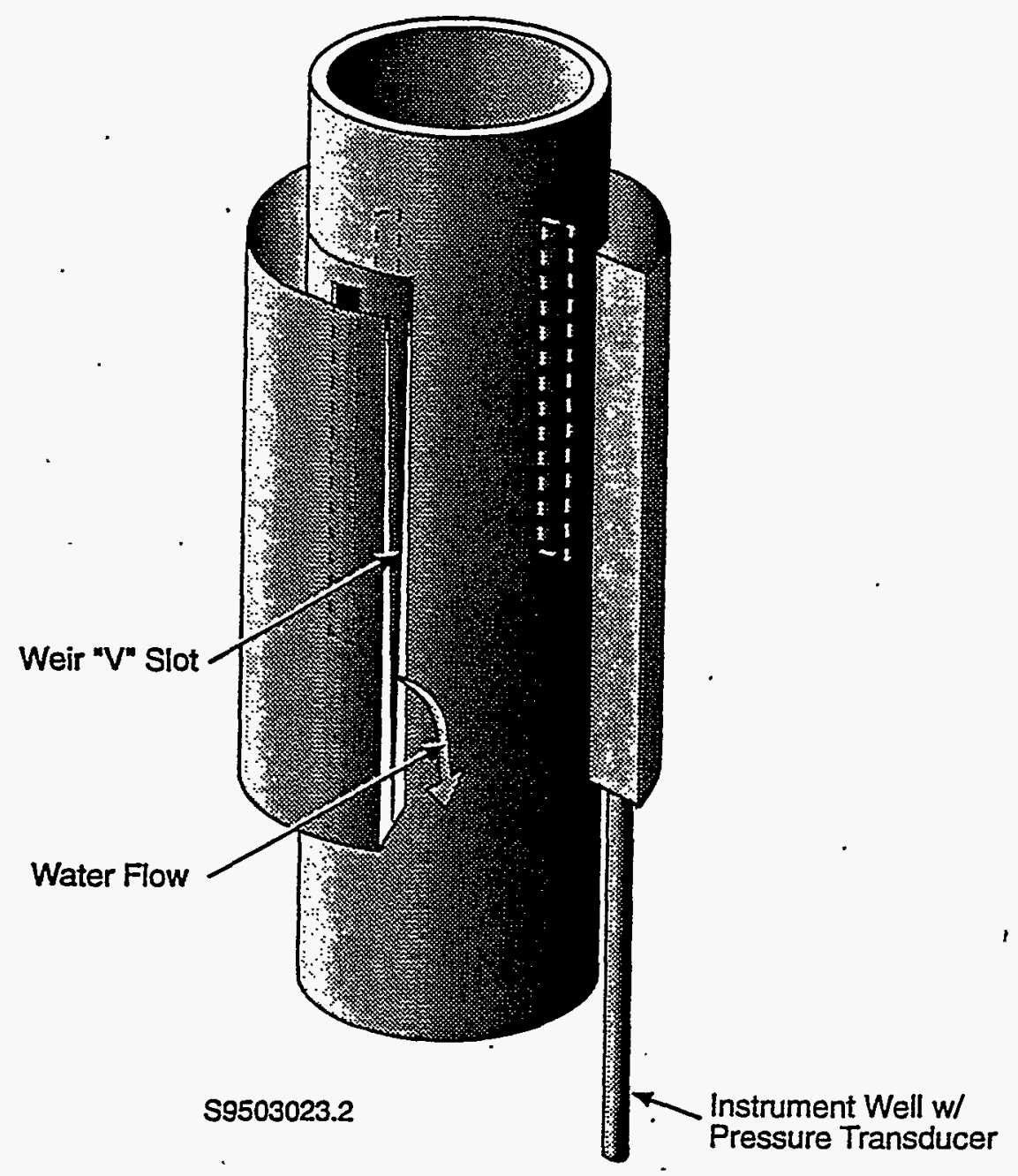

Figure 4. Down-Well Water-Flow Meter (Weir)

To measure water flow through the system, in the field application a cylindrical weir was constructed and calibrated in the laboratory. The weir fit around the 6-in. $(15.2-\mathrm{cm})$ inner casing just below the openings that allow water to exit the 6-in. $(15.2-\mathrm{cm})$ tubing into the 10 -in. $(25.4-\mathrm{cm})$ tubing. The weir intercepted the water leaving the 6 -in. $(15.2-\mathrm{cm})$ casing and channelled the water over a "V" slot notch. The height of the water behind the "V" notch could be related to water-flow rates. The weir and associated casing were constructed of stainless steel for later use in the field demonstration (see Down-Well Water-Flow Meter section) (Figure 4).

\subsection{Measurement Instrumentation}

The laboratory apparatus was instrumented with 7 pressure transducers located every $10 \mathrm{ft}(3.1 \mathrm{~m})$ in elevation from just above the sparging element at $5 \mathrm{ft}(1.5 \mathrm{~m})$ off the bottom to $65 \mathrm{ft}(19.8 \mathrm{~m})$ in 
elevation. An eighth pressure transducer was located in the weir to measure water height in the weir, which could be related to water flow. Two paddlewheel-type flow meters were placed at both the inlet flow line from the holding tank to the 10 -in. $(25.4-\mathrm{cm})$ tubing and the return line from the 10 -in. $(25.4-\mathrm{cm})$ tubing to the holding tank. These flow meters measured the water-flow rate in the system and were also used to calibrate the weir.

Thermocouple wires were placed at 15,35 , and $65 \mathrm{ft}(6.1,10.7$, and $19.8 \mathrm{~m})$ off the bottom to measure the water temperature in the column. In addition, thermocouple wires were placed in the water-holding tank, the exhaust air manifold, and the inlet air line to measure air temperatures.

A hydrometer and vacuum gauge were placed in the exhaust air line to measure humidity and the vacuum pressure in the laboratory's vent system. In addition to the physical parameters measured, high-resolution black-and-white video cameras were placed every $10 \mathrm{ft}(3.1 \mathrm{~m})$ of the column length between the 5- and 55- $\mathrm{ft}$ (1.5- and 16.8-m) levels to record the experiments. A bank of video monitors was used to watch the flow experiment in the column during testing. A sixth camera was used at the $50-\mathrm{ft}(15.3-\mathrm{m})$ level to record a wide-angle view of the column. The videotape from this camera was used to measure bubble size and velocity up the column. Data loggers were used to electronically record the temperature, pressure, water-flow rate, humidity, and exhaust line vacuum.

\subsection{Design of System Components}

\subsection{Down-Well Water-Flow Meter}

An important parameter to measure during the operation of the in-well vapor-stripping system, particularly in the planned field demonstration, is the water-flow rates that are induced by the air injection. Because water is not withdrawn from the well casing, a means to measure the water flow within the casing is needed. The traditional measurement of water-flow rate by a paddlewell flow meter cannot work with the system because of the large-diameter casing and the turbulent flow of the air and water mixture.

To measure this flow, a weir was suggested. A traditional weir measures flow in a channel, and water is directed over a "V" notch of known dimensions and the height of water behind the " $\mathrm{V}$ " notch is related to the water-flow rate in the channel. An adaption of this concept was developed in the form of a downhole weir. The in-well application of this weir captures vertical flow of water in the well casing and channels it across a "V" notch. The height of the water in the weir can be remotely monitored using a pressure transducer. A stilling well, or pipe, was fitted below the weir for the transducer. This minimized turbulence around the transducer and "pre-loaded" the transducer with approximately $2 \mathrm{ft}(0.61 \mathrm{~m})$ of water.

The weir is shaped as a partial cylinder that wraps around the 6-in. $(15.2-\mathrm{cm})$ tubing inside the annulus between the 6- and 10-in. (15.2- and 25.4-cm) casings. The weir wraps approximately 270 degrees around the casing, leaving an open area that allows water to drain from the weir and an area to pass downhole equipment beyond the weir (see Figure 4). The weir was constructed of 
stainless steel, so that it could be transferred directly to the field demonstration after being calibrated in the laboratory experiments. The weir was designed to measure flow rates between 10 and $40 \mathrm{gal} / \mathrm{min}$. For this flow range, the height of the notch in the weir was 10.25 in. $(26 \mathrm{~cm})$. There were 3 openings in the 6-in. $(15.2-\mathrm{cm})$ pipe that allowed water to enter the weir. The openings were $8 \mathrm{in} .(20.3 \mathrm{~cm})$ long and 1.5 in. $(3.8 \mathrm{~cm})$ wide. This is the first known application of a weir inside a borehole.

\subsubsection{Resolution of Flow}

The water level in the weir can fluctuate greatly and is, in part, controlled by the flow regime in the 6-in. $(15.2-\mathrm{cm})$ tubing. The more turbulent the flow in the tubing, the more water-level variation in the weir. At a submergence-to-lift ratio of $45: 20$ and flow rates that ranged from 4.1 to $43.5 \mathrm{gal} / \mathrm{min}$, which is slightly greater than the designed range of the weir, the average height of water in the weir ranged from 0.37 to $1.43 \mathrm{ft}(0.11$ to $0.44 \mathrm{~m})$. Typical variation in height of water in the weir at any given flow rate was on the order of $\pm 0.14 \mathrm{ft}( \pm 0.04 \mathrm{~m})$ but varied by as much as $\pm 0.26 \mathrm{ft}$ $( \pm 0.08 \mathrm{~m})$, or $18 \%$, of full scale at the highest flow rates. The turbulence of the system is believed to produce these height variations. A $0.04-\mathrm{ft}(0.01-\mathrm{m})$ change in the height of water in the weir equates to approximately a 1-gal/min flow rate. Therefore, the flow rate measured by the weir varied by as much as $\pm 6.5 \mathrm{gal} / \mathrm{min}$ from the flow-meter reading in the laboratory. The accuracy may be improved by averaging over a larger number of readings; typically, between 5 and 10 readings were recorded at $1 / \mathrm{min}$ for each static flow rate in the laboratory. To calibrate the weir, several sets of data that were averaged over each static setting in the laboratory were graphically represented as flow rate (gallons per minute) versus the height in the weir. A best-fit line was then determined. A correlation factor of 0.964 was obtained with a power function of $y=x^{1.68} * 22.884$, where $y$ is the water-flow rate and $x$ is the height in the weir (Figure 5). At lower submergence ratios and/or higher flow rates, the turbulence in the system increases and the variability of the height of water in the weir also increases. Under the expected system operating ranges for the planned field demonstration, the weir measures water-flow rates reasonably well. Simple modifications to the weir are planned that would minimize the transfer of turbulence from the inner casing to the weir and, therefore, increase the accuracy of the water-flow measurements.

An alternate method to determine water-flow rates in the system is to use the set of empirical operating curves developed during the laboratory experiments. These operating curves can also be used to determine the water-flow rates based on total lift and inlet air-flow volume. The lift and inlet air-flow volumes can each be determined in the field relatively easily and these operating curves could be used in lieu of the downhole weir. The operating curves shown in Figure 6 include total lifts ranging between 20 and $35 \mathrm{ft}(6.1$ and $10.7 \mathrm{~m})$ in $5-\mathrm{ft}(1.5-\mathrm{m})$ increments. The volume of air required to lift the water depends on the total pumping lift, the pumping submergence, and the area of the annulus between the eductor and the casing wall. The configuration of the laboratory experiment was a pipe diameter of 6 in. $(15.2 \mathrm{~cm})$ and an eductor pipe of 1 in. $(2.5 \mathrm{~cm})$. The eductor pipe was centered in the well to minimize its contact with the acrylic tubing. The area of the annulus could be increased by moving the pipe to the wall of the casing. This could perhaps minimize some of the coalescence of the bubbles in the column and increase lift capacity. 


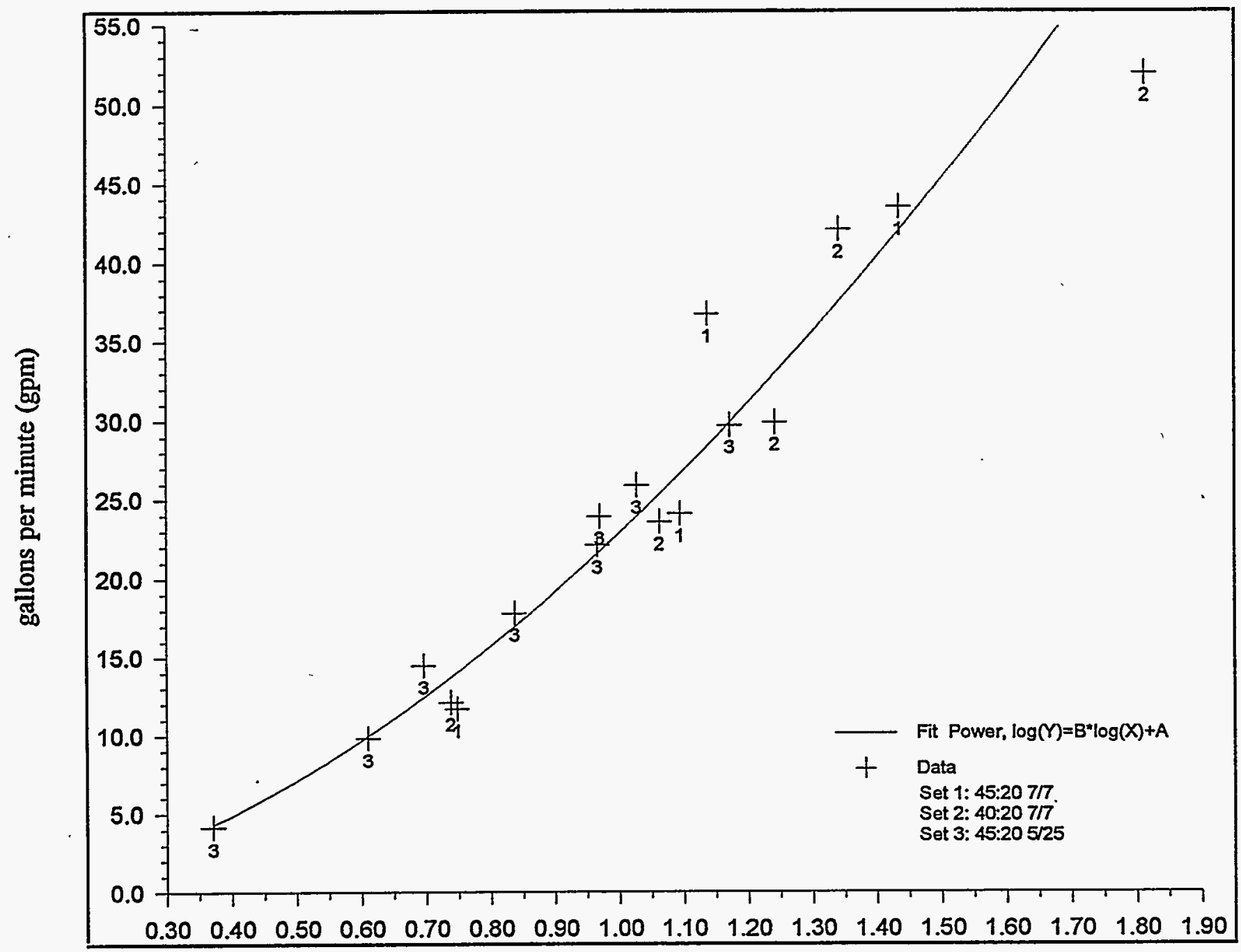

height of water in weir (ft)

Figure 5: Power Function Determination for Weir Calibration

\subsection{Diffuser Performance}

Three different diffusers with openings of 100 microns, 400 microns, and $1.5 \mathrm{~mm}$ were used on the end of the air line to produce the bubbles. From the experiments, however, it was determined that the initial size of the diffuser openings did not have a significant effect on the flow regime in the column. Although the openings at the diffusers varied over a wide range, the majority of the bubbles appeared to coalesce on the surface of the diffuser. This was particularly true of the 100 - and 400 -micron diffusers. Observations from videotape indicate that while there is a swarm of very small bubbles ( $<1 \mathrm{~mm}$ ) leaving the 100- and 400-micron diffusers, many of the bubbles coalesce to 0.4 to $1.2 \mathrm{in}$. $(1 \mathrm{to} 3 \mathrm{~cm})$ very near to and on the surface of the diffuser. For the $1.5-\mathrm{mm}$ wire mesh diffuser, 


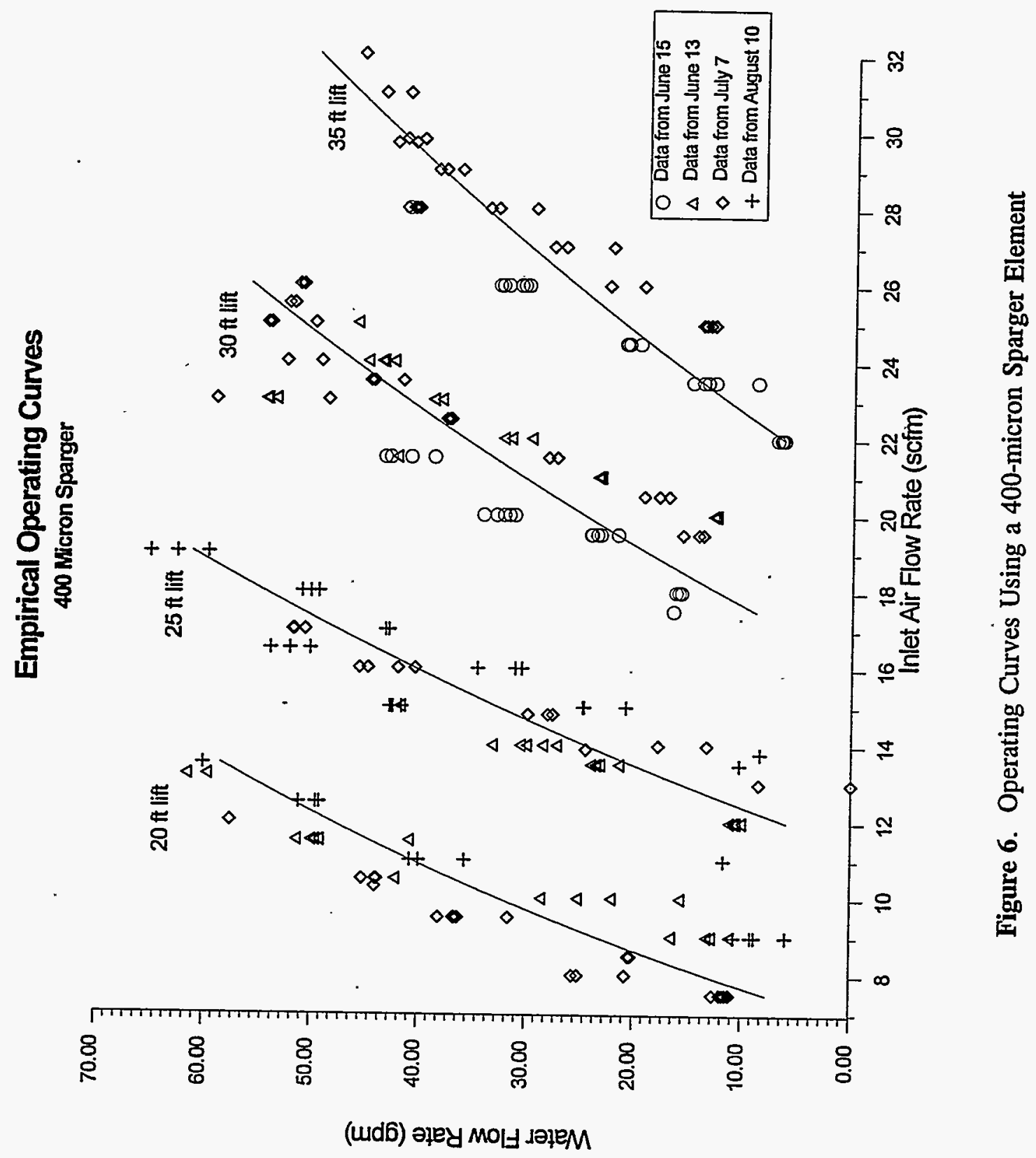


the bubbles leaving the diffuser are in the millimeter range but also coalesced quickly very near the diffuser. For all diffusers, a bubble swarm circulates around the diffusers where the bubbles continue to coalesce. The bubbles by the $10-\mathrm{ft}(3.1-\mathrm{m})$ level in the column have developed into the larger elongate bubbles referred to as Taylor bubbles (Figure 7; from Bilicki and Kestin 1987 Taylor bubble p. 289). The bubbles continue to coalesce as they move up the column to where, at the 50-ft (15.3-m) level, the Taylor bubbles ranged in length from 2 to $5 \mathrm{ft}(0.61$ to $1.5 \mathrm{~m})$ (see section on Flow observations). The Taylor bubbles were well developed by the $50-\mathrm{ft}(15.3-\mathrm{m})$ height of the column, regardless of the initial sparging element used. The results of the laboratory experiment indicate that the diffuser size does not have a significant effect on the final bubble sizes and, therefore, on the flow regime in the column. This is also supported by the observations of Towell et al. (1965), who found that different diffuser designs had little effect on bubble size.

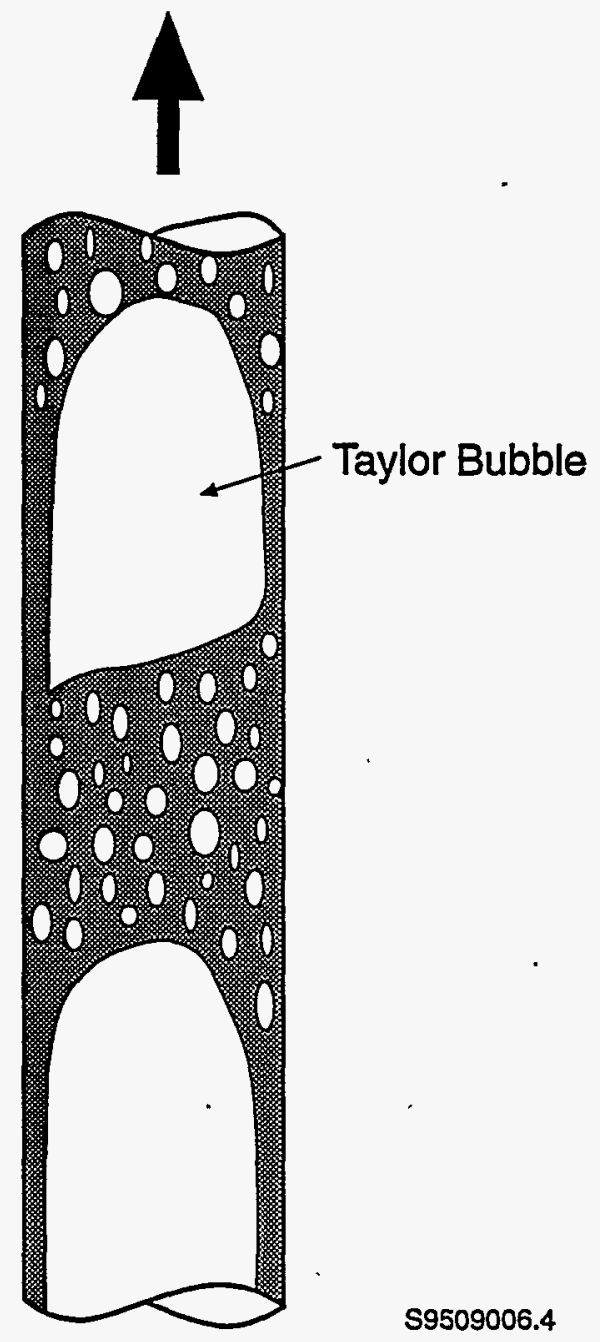

Figure 7. Taylor Bubbles 


\subsection{System Operating Parameters}

\subsection{Mass Transfer}

The variables required to determine the mass transfer of the system are related in the following equations. The laboratory experiment was designed to determine these variables experimentally. Ideally, the mass transfer between gas and liquid phases is characterized by the Boussinesq equation:

$$
N_{S h}=\sqrt{\frac{4}{\pi} N_{P e}^{1 / 2}}
$$

where $N_{P_{e}}=$ peclet number, where $N_{P_{e}}=D_{b} u_{t} / D$

$D_{b}=$ bubble diameter $(m)$

$\mathrm{u}_{\mathrm{t}}=$ terminal bubble velocity of rise $(\mathrm{m} / \mathrm{s})$

$\mathrm{D}=$ diffusivity $\left(\mathrm{m}^{2} / \mathrm{s}\right)$.

In practice, however, the mass-transfer coefficient in the sherwood number $\left(N_{S h}=k_{L} D_{b} / D\right)$ is dependent on mean bubble size, where $k_{L}$ is the mass-transfer rate constant ( $\left.m / s\right)$ (Miller 1993). The mass transfer of VOCs in solution to vapor in the column is dependent on 1) flow regime, 2) interfacial area, and 3) mean bubble size. Interfacial area is inversely dependent on the mean bubble size, and the mass-transfer constant is directly dependent on the diameter of the bubbles (Miller 1993). The determination of the bubble sizes in bubble columns is not a trivial matter; they are controlled by various interdependent variables. The following experimental observations are intended to help develop the conceptual model and provide the values necessary to determine a mass-transfer rate in the system. Additionally, the mass-transfer rate, or stripping efficiency, were deterimined experimentally. Please see the Stripping Efficiency Tests section for these results.

\subsection{Flow Regime}

In the literature, so-called transition "maps" for the upward flow of air in water have been developed (Taitel et al. 1980; Bilicki and Kestin 1987). The flow regimes have been defined based on the superficial velocities of the air and water phases which in turn are dependent on the air to water ratios, the column diameter and percent submergence. The regimes range from bubble flow, to slug flow, to churn flow, to annular flow (Figure 8, from Taitel et al. 1980 p. 346). Bubble flow is a series of single spherical bodies that move through the column of water. Slug flow occurs as bubbles begin to coalesce into slugs or Taylor bubbles (see Figure 7). Churn flow is similar to slug flow, however, it is much more chaotic, frothy, and disordered (Taitel et al. 1980). Bilicki and Kestin (1987) replace the churn flow of Bilicki with a froth flow and describe the froth flow as the coalescence of the Taylor bubbles. Finally, annular flow is when an air stream is formed through the liquid in the column. The flow regime will affect the interfacial area for mass transfer as well as affect the lift (pumping) capacity of the water within the column. 


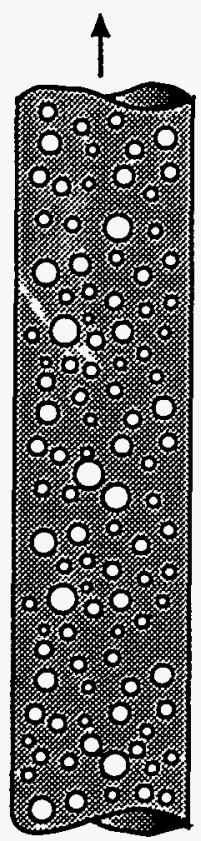

Bubble Flow

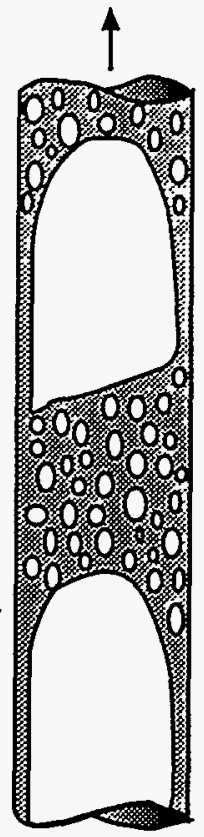

Slug

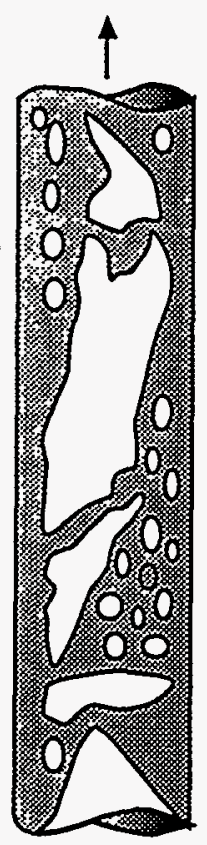

Chum
(Froth
Flow)

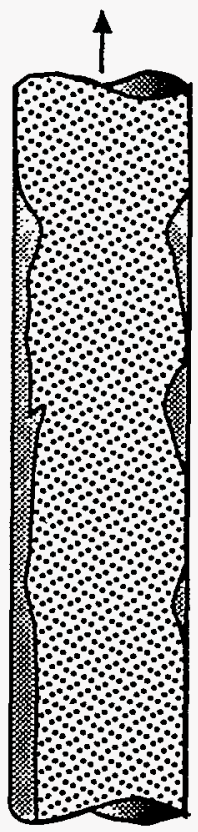

Annular

Flow

S9503023.3

Figure 8. Flow Regimes (after Taitel et al. 1980)

Before conducting the laboratory experiments, it was thought that the system should be operated in the bubble flow regime to maximize the stripping efficiency of the system while maintaining efficient lift of the water inside the column. This was considered for two reasons: 1) the most efficient lift occurs in the bubble-flow regime and 2) by limiting the size of the bubbles, the gas-liquid interfacial area would be maximized leading to higher mass-transfer rates. It was observed in the laboratory, however, that the system passes through the bubble-flow regime very rapidly. With sparger submergences of 35 to $50 \mathrm{ft}(10.7$ to $15.3 \mathrm{~m})$, the water could only be lifted level inside the 6-in. $(15.2-\mathrm{cm})$ column 8 to $12 \mathrm{ft}(2.44$ to $3.66 \mathrm{~m})$ before the bubble-flow regime gave way to the slug-flow regime. The pipe diameter and liquid viscosity also affect flow regime, but for the laboratory experiment, these variables were constant. There are several papers in the literature that attempt to predict the flow patterns under given circumstances. From a review of these papers, it is apparent that the subject is intrinsically complex, and an adequate set of parameters that determine the pattern remains to be discovered (Bilicki and Kestin 1987). For the practical application of the in-well vapor-stripping system, the laboratory observations indicate that the system's configuration; depth of sparger and the required lift height (submergence to lift ratio), will primarily determine what flow regime the system will be in. The system's configuration will be determined 1) by the contact time required for the dissolved VOCs to partition into the vapor phase and in field applications, 2) by the vadose zone and 
aquifer thicknesses, and 3) the lift required to maximize the size of the groundwater circulation cell around the well. It is expected that the field operation of the system will also be predominantly be in the slug-flow regime.

In the slug-flow regime, the bubbles in the column were large bullet-shaped bubbles, called Taylor bubbles, that had froth formation at the trailing edges of the bubbles. The air and water mixture in the wake of the bubbles was very turbulent, with back eddys of water that would fall downward between advancing slugs.

Stop-action videotape recordings of the test column were analyzed to obtain the length, period, and velocity of the slugs (i.e., bubbles). These observations can be used to determine the velocity of the air through the column and estimate the interfacial area required in mass-transfer calculations. At $30-\mathrm{ft}(9.2-\mathrm{m})$ submergence and $40 \mathrm{ft}(12.2 \mathrm{~m})$ of lift, the average length of slug was just over $5 \mathrm{ft}$ $(1.5 \mathrm{~m})(5.2 \mathrm{ft}[1.6 \mathrm{~m}]$ at an elevation of $50 \mathrm{ft}[15.3 \mathrm{~m}]$ in the tube and between the water-flow rates of 8.5 to $40 \mathrm{gal} / \mathrm{min}$ ). The length of slug did not vary significantly over the range of water-flow rates, and the slug velocity (air velocity) did not increase significantly over the range of water-flow rates and air volumes. Harmathy (1960 from Taitel 1980) also demonstrated that the velocity of relatively large bubbles is insensitive to the bubble size.

The next higher flow regimes, churn (frothing) and annular flow, were never reached in the laboratory. When air was injected into the system at flow rates greater than $30 \mathrm{stt}^{3} / \mathrm{min}(849 \mathrm{l} / \mathrm{min})$, the water in the system was forced into the laboratory vent system, requiring the system to be shut down. Modification to the laboratory setup is required before it can handle the high air volumes required to enter into the churn or annular flow. The transition to churn flow, however, may have been approached. At the highest air-flow rates $\left(\sim 30 \mathrm{stt}^{3} / \mathrm{min}[\sim 849 \mathrm{l} / \mathrm{min}]\right)$ and the highest lift (35 $\mathrm{ft}$ $[10.7 \mathrm{~m}])$, the water in the column becomes very turbulent and the well-formed Taylor bubbles begin to lose some of their well-defined shaped as the heads of the bubbles begin to deform. The system appeared to be in the transition to churn flow.

The mass-transfer process is governed by the surface contact area of vapor and liquid, by the flow rates of the liquid and gas, and by the equilibrium curve for the solute. The complicating factor is determining the surface contact area. Through observation, however, the size of the bubbles may not have the profound effect on the mass-transfer rates as initially perceived. The slug-flow regime is extremely turbulent, creating frothing of the liquid and water between each slug. This violent mixing of air and water is undoubtedly promoting the partitioning of the VOCs from the water to the air.

\subsection{Miscellaneous Observations}

\subsection{Cyclic Patterns}

Visually, the slug movement appeared to have some cyclic pattern to it. The time was measured between successive slugs crossing the $50-\mathrm{ft}(15.3-\mathrm{m})$ level of the column using videotape analysis. The closest the slugs were spaced was $0.39 \mathrm{~s}$ apart, and the furthest spacing was $0.61 \mathrm{~s}$ between slugs. The 
spacing would increase and then decrease on a frequency of every 2 to 3 slugs. The static water levels in the outer 10-in. $(25.4-\mathrm{cm})$ casing that supplied water to the system also fluctuated up and down $(\sim 0.3 \mathrm{ft}[\sim 0.09 \mathrm{~m}])$ on a regular cycle.

\subsection{Air-to-Water Flow Rate Ratios and Air Holdup Calculations}

The air-to-water ratio is the ratio of the flow rate of air to the flow rate of water. For these series of experiments, the air-to-water ratios ranged from approximately 1:1 to 30:1. The lowest air-to-water ratios were recorded when the submergence of the diffuser was greatest $(45 \mathrm{ft}[13.7 \mathrm{~m}])$ and the height the water needed to be lifted above the static water level, or lift was the smallest $(20 \mathrm{ft}[6.1 \mathrm{~m}])$. Conversely, the largest air-to-water ratios were when submergence was lowest $(30 \mathrm{ft}[9.2 \mathrm{~m}])$ and the lift was greater ( $35 \mathrm{ft}[10.7 \mathrm{~m}])$. These air-to-water ratios are expected to have the largest impact on the stripping efficiency of the system. The higher the air-to-water ratios, the greater the stripping efficiency of the system.

The holdup, or volume of air, in the column at any one instant was measured by simultaneously closing the air inlet, water inlet, and water outlet. The system was then allowed to equilibrate and the measurement was taken of the volume of water and air trapped in the 6 -in. $(15.2-\mathrm{cm})$ column. The air holdup in the system was always found to be equal to the total height of lift. For example, when the static water level in the 10-in. $(25.4-\mathrm{cm})$ annulus was at a height of $50 \mathrm{ft}(15.3 \mathrm{~m})$ and the required lift height above this static water level was $20 \mathrm{ft}(6.1 \mathrm{~m})$, the amount of air in the column was approximately equal to $20 \mathrm{ft}(6.1 \mathrm{~m})$. These holdups were measured over a 5- to 50-gal $/ \mathrm{min}$ range of waterflow rates and with varying static water levels and lifts. Flow losses appear to be small, or at least too small to measure using this technique.

\subsection{Aeration of Water Returning to the Formation}

The water that enters the outer casing did not appear overly aerated. Most of the degassing may have occurred in the weir before entering the 10-in. $(25.4-\mathrm{cm})$ casing. The water did appear translucent, with small bubbles, but cleared up rapidly. If the water backed up a foot or two before being drained from the 10 -in. $(25.4-\mathrm{cm})$ annulus, it was nearly transparent.

\subsection{Potential of Injecting Air into the Formation}

Videotape of the sparging elements shows that very few bubbles move below the sparger but have a very strong tendency to move up in the column. The bubble swarm rarely extends below the sparging element, even at the highest flow rates $\left(67 \mathrm{lb} / \mathrm{in} .{ }^{2}\right.$ abs., $\left.28 \mathrm{stt}^{3} / \mathrm{min}\right)$ used in the laboratory. This would indicate that, in practice in a borehole, if the sparging element were placed just above the screened section, it would be very unlikely that any bubbles would enter into the screened area and into the sediments. All the aeration would occur in the casing. 


\subsection{Hydrometer Readings}

The hydrometer readings of the outlet air after the air had traveled through the column were very near saturation. The readings were generally $97 \%$ to $100 \%$ humidity during the operation of the system. The humidity would decrease very slightly $(<1 \%)$ as the volume of injected air was increased. The humidity readings would, however, always remain above $95 \%$ despite the volume of air injected or the height of lift. We are expecting treating off-gas in the field at near $100 \%$ humidity.

\subsection{Temperature Readings}

Thermocouples were placed every $10 \mathrm{ft}(3.1 \mathrm{~m})$ in the column and the temperature was measured before, during, and after operation of the system. The inlet air temperatures were not significantly higher than the water temperatures in the column because the source of the compressed air (building air supply) was a long distance from the laboratory setup and then air had a chance to equilibrate with the laboratory temperature. Therefore, the water and air temperature variations in the column were not significant.

\subsection{Stripping-Efficiency Tests}

\subsection{Selection of Test Contaminant for Stripping Tests}

Several VOC contaminants for use in conducting the stripping tests were considered, including freon, ammonia, and propane, as well as the suite of chlorinated hydrocarbons (e.g., trichloroethylene [TCE], 1,1,1-trichloroethane [TCA], carbon tetrachloride, etc.). Freon, ammonia, and propane were considered because there are detectors commercially available that could be easily incorporated into the test setup, but were rejected because their physical properties were significantly different from the targeted contaminants at the field demonstration site and the Hanford Site test locations. It was determined that a chlorinated hydrocarbon should be used, if possible. The selection of a chlorinated hydrocarbon, however, presented both technical and practical concerns. From a practical standpoint, there was concern for the safety of the operators in the laboratory and for disposal of the waste. Technically, there was concern because the test column was constructed of acrylic and organic solvents have an affinity for acrylic (i.e., there would be some sorption and desorption of the organic solvents onto the acrylic).

The chlorinated hydrocarbons selected for the stripping-efficiency test was TCA based primarily on the similarities of its physical properties to carbon tetrachloride and TCE and its lower health risks for handling in the laboratory and less-stringent disposal standards. TCA is ranked 9th in the most frequently detected groundwater contaminant at hazardous waste sites in the United States (by the Agency for Toxic Substances and Disease Control), so the results could be applicable to field situations. Table 2 shows a comparison of some of the characteristics of the VOCs. 


\subsection{Stripping Efficiency of TCA}

The objective of this test was to determine the stripping efficiency of the system in terms of percent contaminant stripped per pass through the system and percent of original concentration removed. Two stripping-efficiency tests were conducted; they were identical in sampling frequency and location. Several aspects of the first test were refined for the second test and, in particular, the mixing of the TCA into solution and the air-outlet sampling port were modified in the second test after identifying improvements from the first experiment.

\subsection{Methods}

The stripping unit was operated to simulate field conditions; namely, $30 \mathrm{ft}(9.2 \mathrm{~m})$ of lift at a flow rate of $20 \mathrm{gal} / \mathrm{min}$. Although slightly higher flow rates might be achieved in the field, the system's configuration for the stripping test yielded a maximum flow rate of $20 \mathrm{gal} / \mathrm{min}$. The contaminant used in the experiment was TCA at an initial concentration of $410 \mu \mathrm{g} / \mathrm{L}$.

To begin the test, the TCA was mixed in 75-gal batches and distributed in the system. Because the sorption/desorption tests showed residence time of the contaminant has an effect on its sorption to the acrylic, the mixing of the TCA solution was done as quickly as possible. Three batches of TCA were mixed in the holding tank and then released to the column. A stock solution of TCA was measured by pipette and then released to the holding tank. The holding tank was then stirred (with minimum agitation) to enhance mixing and then released to the column. Total water in the system was approximately $226 \mathrm{gal}$, and the total time required for mixing was approximately $1 \mathrm{~h}$.

To determine the stripping efficiency of each cycle through the system, the sampling episodes were based on the system's circulation time. Samples were collected at the very start of the test and then

Table 2. Characteristics of Chlorinated Hydrocarbons

\begin{tabular}{|c|c|c|c|}
\hline Characteristic & $\begin{array}{l}\text { Trichloroethylene } \\
\text { (TCE) }\end{array}$ & Carbon Tetrachloride & $\begin{array}{l}\text { 1,1,1-Trichloroethane } \\
\text { (TCA) }\end{array}$ \\
\hline Formula & $\mathrm{CHClCCl}_{2}$ & $\mathrm{CCl}_{4}$ & $\mathrm{CH}_{3} \mathrm{CCl}_{3}$ \\
\hline Formula weight & 131.38 & 153.82 & 133.40 \\
\hline Henry's law constant & $\begin{array}{l}0.00842 \mathrm{~atm} \mathrm{~m} / \mathrm{mol} \mathrm{@} \\
20^{\circ} \mathrm{C}\end{array}$ & $\begin{array}{l}0.024 \mathrm{~atm} \mathrm{~m} / \mathrm{mol} @ \\
20^{\circ} \mathrm{C}\end{array}$ & 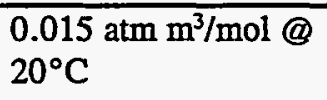 \\
\hline $\begin{array}{l}\text { Time-weighted average } \\
\text { exposure limit }\end{array}$ & $25 \mathrm{ppmv}$ & $2 \mathrm{ppmv}$ & 10 ppmv \\
\hline Disposal concentration ${ }^{(2)}$ & $5 \mu \mathrm{g} / \mathrm{L}$ & $5 \mu \mathrm{g} / \mathrm{L}$ & $200 \mu \mathrm{g} / \mathrm{L}$ \\
\hline Carcinogen & Suspected & Suspected & Data not available \\
\hline
\end{tabular}


once per cycle. The time for each cycle in the column was determined by tracer tests. Food coloring was added to the column as a tracer, and the circulation time of the colored water was measured. During these tracer tests, a stagnant zone was identified in the 10 -in. $(25.4-\mathrm{cm})$ casing above the return flow line from the holding tank. To eliminate the stagnant zone, the system was replumbed for the stripping tests, so that the inlet line could be placed right at the static head level in the 10 -in. $(25.4-\mathrm{cm})$ casing. The tracer tests were rerun, and the average time for the tracer to circulate was $6.5 \mathrm{~min}$. Based on this result, samples from the column were collected at 7-min intervals for the first 5 cycles and then at 7,11, and 14 cycles (Table 3). Both water and air samples were collected. Air-sampling points were located at the outflow manifold and at the inlet to the system from the building compressed air system. Water-sampling points were at the inlet to the 6 -in. $(15.2-\mathrm{cm})$ casing near the bottom of the system, at the weir near the top of the system, and in the holding tank (see Figure 2). All samples were collected simultaneously at the time intervals. Water samples were collected using $40-\mathrm{mL}$ amber glass volatile organic analysis bottles and analyzed by gas chromatography in the laboratory.

\subsection{Test 1 Results}

The initial TCA concentration was $410 \mathrm{ppb}$ and the final concentration after $98 \mathrm{~min}$, or approximately 14 cycles, was $2.7 \mathrm{ppb}$. The stripping efficiency for each of the first 5 passes through the system was approximately $50 \%$ (Figure 9).

\subsection{Modification to Methods}

Some aspects of the test were refined before operating the second test. This included better mixing of the TCA and a better sampling setup for the outlet air. In the first test, mixing the TCA was awkward in the holding tank. Enough stock solution of TCA was added to the holding tank for an initial concentration of $4000 \mathrm{ppb}$ but the initial concentration measured was $410 \mathrm{ppb}$. A recheck of the calculations for mixing the stock solution of TCA found them correct and, therefore, most of the TCA

Table 3. Sampling Times and Locations

\begin{tabular}{||l|c|c|c|c|c|c|c|c|c||}
\hline \multicolumn{1}{|c|}{$\begin{array}{c}\text { Sample } \\
\text { Location }\end{array}$} & $\begin{array}{c}\text { Sample } \\
\text { Time } \\
0 \mathrm{~min}\end{array}$ & $\begin{array}{c}\text { Sample } \\
\text { Time } \\
7 \mathrm{~min}\end{array}$ & $\begin{array}{c}\text { Sample } \\
\text { Time } \\
14 \mathrm{~min}\end{array}$ & $\begin{array}{c}\text { Sample } \\
\text { Time } \\
21 \mathrm{~min}\end{array}$ & $\begin{array}{c}\text { Sample } \\
\text { Time } \\
28 \mathrm{~min}\end{array}$ & $\begin{array}{c}\text { Sample } \\
\text { Time } \\
35 \mathrm{~min}\end{array}$ & $\begin{array}{c}\text { Sample } \\
\text { Time } \\
49 \mathrm{~min}\end{array}$ & $\begin{array}{c}\text { Sample } \\
\text { Time } \\
63 \mathrm{~min}\end{array}$ & $\begin{array}{c}\text { Sample } \\
\text { Time } \\
98 \mathrm{~min}\end{array}$ \\
\hline \hline Inlet air & $\mathrm{X}$ & & & & & & & & \\
\hline Outlet air & $\mathrm{X}$ & $\mathrm{X}$ & $\mathrm{X}$ & $\mathrm{X}$ & $\mathrm{X}$ & $\mathrm{X}$ & $\mathrm{X}$ & $\mathrm{X}$ & $\mathrm{X}$ \\
\hline $\begin{array}{l}\text { Holding tank } \\
\text { (water) }\end{array}$ & $\mathrm{X}$ & $\mathrm{X}$ & $\mathrm{X}$ & $\mathrm{X}$ & $\mathrm{X}$ & $\mathrm{X}$ & $\mathrm{X}$ & $\mathrm{X}$ & $\mathrm{X}$ \\
\hline $\begin{array}{l}\text { 6-in. } \\
\text { (15.2-cm) } \\
\text { Inlet (water) }\end{array}$ & $\mathrm{X}$ & $\mathrm{X}$ & $\mathrm{X}$ & $\mathrm{X}$ & $\mathrm{X}$ & $\mathrm{X}$ & $\mathrm{X}$ & $\mathrm{X}$ & $\mathrm{X}$ \\
\hline Weir (water) & $\mathrm{X}$ & $\mathrm{X}$ & $\mathrm{X}$ & $\mathrm{X}$ & $\mathrm{X}$ & $\mathrm{X}$ & $\mathrm{X}$ & $\mathrm{X}$ & $\mathrm{X}$ \\
\hline
\end{tabular}




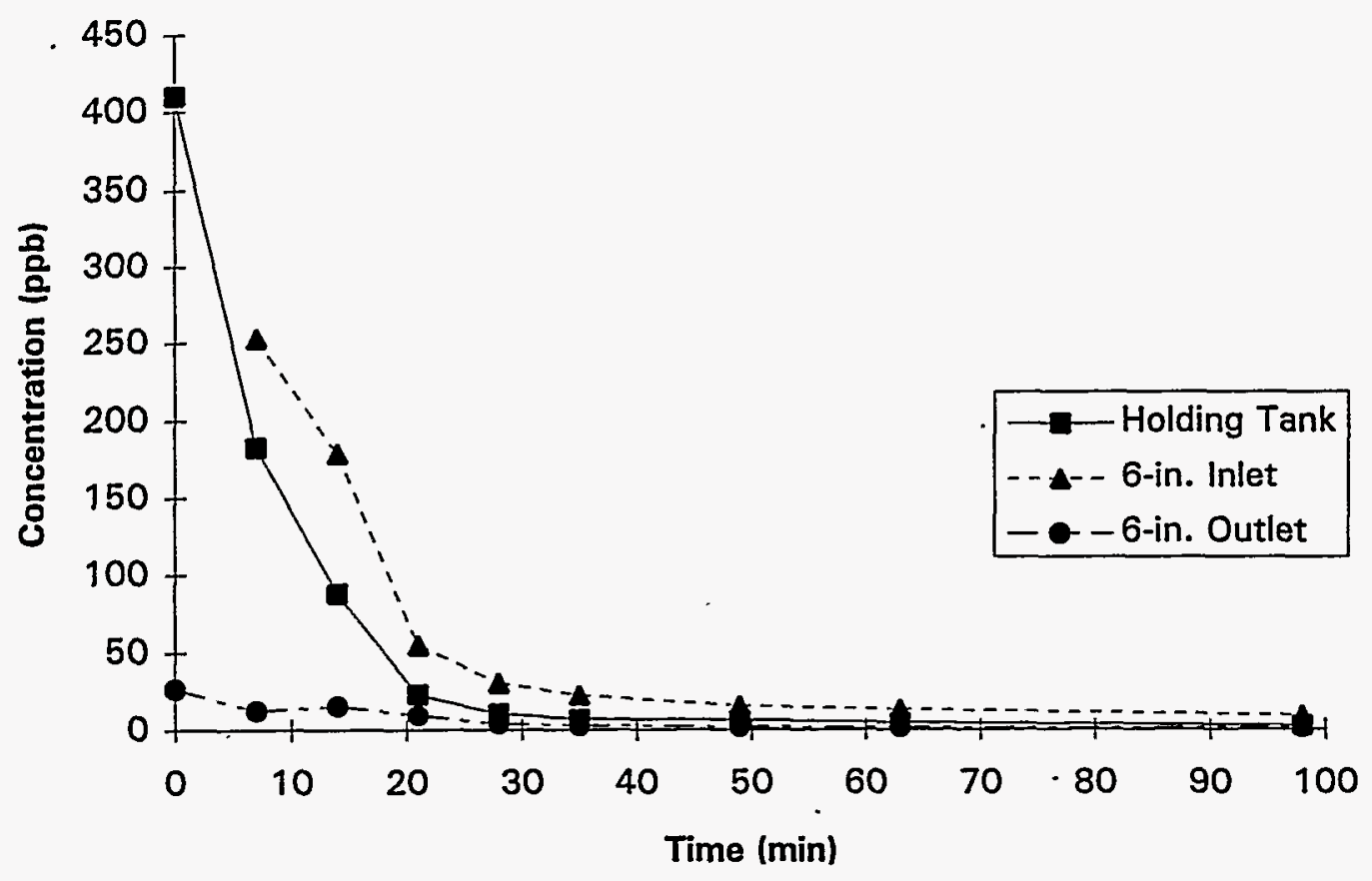

Figure 9. Stripping Efficiency of TCA

is believed to have volatilized off during mixing into the water. The TCA was placed onto the top of the water in the holding tank using a pipette and then mixed into the tank with a stirring rod. The water was then released to the column, and this step was repeated three times. To eliminate the volatilization by adding TCA to the water surface in the second test, the TCA was injected into the holding tank through an injection port just above the outlet to the test column. The measured concentrations were very different from the calculated concentrations, based on the quantity of stock solution added. This would indicate that the TCA was either volatilized in the test column or from the holding tank. TCA is also immiscible in water, and a thorough mixing with water is difficult.

For the second test, the outlet air sampling port was also modified to allow larger volumes of air through the system. The outlet air samples were not representative in the first test. There was virtually no flow exiting out of the sampling port. A very small volume of air was moving through the sampling port even when the vent tube was blocked to force air through the sampling port. It is felt that the sampling port was too small $(\sim 1 / 8$ in. $[\sim 0.32 \mathrm{~cm}])$ and out of the main stream of air. To alleviate this problem, a larger sampling port was added for the second test and was placed more in the main stream of air.

\subsection{Test 2 Results}

Despite the efforts to inject the TCA below the water surface, the initial concentration of the TCA was $259 \mathrm{ppb}$ and the final concentration after $98 \mathrm{~min}$, or approximately 14 cycles, was $10 \mathrm{ppb}$. The stripping efficiency for each of the first 3 cycles was $81 \%, 60 \%$, and $34 \%$, respectively. After the third pass, the concentration decline leveled off at approximately $10 \mathrm{ppb}$ (see Figure 9). 


\subsection{Discussion}

The final concentration of TCA in the second test is believed to be artificially high, the result of a secondary source of TCA in the system that diffused into solution during the testing. The source could have been the acrylic or possibly a stagnant zone in the system. Potential areas for stagnant zones are in the injection port and the area below the outlet in the holding tank. To test the potential of a secondary source, the test column and the holding tank were refilled with deionized water following the stripping tests and allowed to sit for one week. Water samples were then collected and analyzed to determine if any TCA was desorbing. TCA was found in both the acrylic column at $\sim 0.4 \mathrm{ppb}$ and in the holding tank at $19 \mathrm{ppb}$. TCA in the holding tank could have come from the sampling port or desorption from the tank.

\subsection{Adsorption/Desorption of TCA onto the Acrylic Column}

Prior to the laboratory experiment, it was expected that there would be some adsorption of the VOC onto the acrylic column. The benefits of using acrylic to view the process outweighed the potential effects of adsorption on the stripping tests. To account for the adsorption/desorption of the TCA on the test column, experiments were conducted to determine the magnitude and rate of TCA adsorption and desorbtion onto (or into) acrylic surfaces. Kinetic experiments, as well as adsorption isotherm experiments, were conducted. The kinetic test measured the changes in concentration of TCA over time to determine how fast the TCA in the container would be absorbed and desorbed by the acrylic. The adsorption isotherm experiments measured the total concentrations of TCA that could be adsorbed and desorbed from the acrylic.

Two vessels were constructed of sections of the acrylic used in the laboratory experiment that were cut into 6-in. $(15.2-\mathrm{cm})$-long sections with acrylic tops and bottoms sealed on. The vessels were $3.2 \mathrm{~L}$ in volume. Three access ports were threaded into the vessels. Two of the access ports were fitted for syringes for adding the solutions of TCA and the third access port was used to fill and drain the vessels.

An adsorption/desorption kinetics experiment was conducted with an initial TCA solution of $100 \mathrm{ppb}$. Samples were collected at 10, 20, and $40 \mathrm{~min}, 1.5,3.0,5.5,24$, and $96 \mathrm{~h}$. After the adsorption experiment was completed, the water was drained from the vessel and refilled with deionized water to conduct a desorption kinetics experiment. Not all the water could be removed, which resulted in a small contamination error.

In the adsorption/desorption isotherm experiments, TCA was added to the vessel and allowed to equilibrate for $24 \mathrm{~h}$. TCA was added incrementally each day to obtain initial concentrations of 1,10 , 1000 , and $10,000 \mathrm{ppb}$.

\subsection{Discussion}

The results from these experiments suggest that adsorption approaches equilibrium between 5 and $20 \mathrm{~h}$. (The stripping experiment conducted in the test column lasts approximately $98 \mathrm{~min}$ ). 
Uncertainties in the data do not allow a more-precise estimate of the equilibration time. It was estimated that approximately $20 \%$ of the TCA was lost from solution during the experiments. It should be noted, however, that a separate test of the sample-handling technique (laboratory blank) indicated that approximately $10 \%$ of the TCA is actually lost to the atmosphere through volatilization, attesting to the very volatile nature of the TCA. Based on results of the laboratory blank, approximately $10 \%$ of the TCA is actually lost from solution as a result of adsorption onto the walls of the acrylic. Of this amount of TCA lost to the walls of the acrylic, it is estimated that, at most, $20 \%$ is desorbed back into solution.

In very imprecise estimates, $41 \mathrm{ppb}$ of the original $410 \mathrm{ppb}$ TCA solution in the first stripping test could be lost to the acrylic if the solution were allowed to reach equilibrium in the column. Of this $41 \mathrm{ppb}$ sorbed to the acrylic, up to $8.2 \mathrm{ppb}$ could desorb back into solution from the walls of the acrylic. These results indicate that discretion should be applied to interpreting the stripping efficiency of TCA in the lower concentrations $(<10 \mathrm{ppb})$ in the acrylic test column.

\subsection{Conclusions}

The concept of the vapor-stripping system was proved effective for removing VOCs from water in the column. Operating curves that relate the air-injection rates to the resulting water-flow rates for various system configurations were developed for the system. These curves can be used in the field to operate the system for a known configuration. In addition, the laboratory results were used to develop a predictive, physically based air-lift pumping model.

Several well components, including a downhole water-flow-measuring device and a wellhead, were developed and calibrated for the laboratory experiment and were designed to be transferred to the field demonstration. The weir was designed for flows between 10 and $40 \mathrm{gal} / \mathrm{min}$, but proved to be accurate in a broader range between 5 and $50 \mathrm{gal} / \mathrm{min}$.

It was found that the system should be operated in the slug-flow regime under most, if not all, field applications. The slug-flow regime developed when the water was lifted greater than 8 to $10 \mathrm{ft}(2.4$ to $3.1 \mathrm{~m}$ ) in the experimental column. The slug flow developed regardless of the initial bubble size.

The stripping efficiency of one common VOC (TCA) was determined using an air-to-water ratio of 7.5:1 at a flow rate of $20 \mathrm{gal} / \mathrm{min}$ through the system. With this system configuration, the stripping ratio per pass through the well was greater than $50 \%$. This stripping ratio is independent of initial concentration. This stripping ratio can likely be increased by increasing the air-to-water ratios in the well.

\subsection{Suggested Research}

Research in the laboratory testing of this system should continue. Although the original objectives of the laboratory testing were met, there are additional aspects of the system that appeared during the 
laboratory testing that warrant further investigation. The system should be tested at higher air-flow rates to determine the effects on the flow regime and on the stripping efficiency of the column. The higher flow regimes of churn and annular flow were not reached during this round of testing. Slight modifications to the systems would allow for the testing at higher air-flow rates.

Another important area of research would be to test ways to increase the stripping efficiency of the system. This could be accomplished by higher air-to-water ratios and/or using screens in the well to break up the slugs and/or multiple injection points for the air into the system. Each of these modifications should be tested in the laboratory under controlled conditions.

Other areas of research could include stripping-efficiency tests to determine the optimal length of the stripping well and methods to control mineral precipitation in field applications.

\subsection{References}

Akita, K., and F. Yoshida. 1973. "Gas Holdup and Volumetric Mass Transfer Coefficient in Bubble Columns." Ind. Eng. Cham. Process Design Develop. 12 No. 1, 76.

Alimonti, C., and D. Galardini. 1992. "The Modeling of an Air-Lift Pump for the Design of its Control System." European Journal Mech. Eng. 37(3):191-197.

Bilicki, Z., and J. Kestin. 1987. "Transition Criteria for Two-Phase Flow Patterns in Vertical Upward Flow. Int. J. Multiphase Flow 13(3):283-294.

Calderbank, P. H., M. B. Moo-Young, and R. Bibby. 1964. "Coalescence in Bubble Reactors and Absorbers." Chemical Reaction Engineering, Proceedings of the Third European Symposium, pp. 91-110.

Clark, N. N., and R. J. Dabolt. 1986. "A General Design Equation for Air-Lift Pumps Operating in Slug Flow." AIChE J. 32(1):56-64.

Gvirtzman H., and S. M. Gorelick. 1992. "The Concept of in-situ Vapor Stripping for Removing VOCs from Groundwater." Transport in Porous Media 8:71-92.

Harmathy, T. 1960. "Velocity of Large Drops and Bubbles in Media of Infinite and of Restrictived Extent." AIChE J. 6(281).

Husain, L. A., and P. L. Spedding. 1976. "The Theory of the Gas-Lift Pump." Int. J. Multiphase Flow 3:83-87.

Hsueh, K. P., O. J. Hao, and Y. C. Wu. 1991. "Removal of Volatile Organic Compounds in a Rotating Disk Contactor: Batch and Continuous Operation." Research Journal WPCF 63(1). 
Lehrer, J. H. 1971. "Gas Holdup and Interfacial Area in Sparged Vessels." Ind. Eng. Chem. Process Design Develop. 10, No. 1, 37.

Miller, D. N. 1993. "Interfacial Area, Bubble Coalescence and Mass Transfer in Bubble Column Reactors." AIChE J. 29(2):312-319.

Reinemann, D. J., J. Y. Parlange, and M. B. Timmons. 1990. "Theory of Small-Diameter Airlift Pumps." Int. J. Multiphase Flow 16(1):113-122.

Richardson, J. F., and D. J. Higson. 1962. "A Study of the Energy Losses Associated with the Operation of an Air-Lift Pump." Trans. Instn. Chem. Engrs. 40:169-182.

Shaw, S. F. 1920. "Unwatering the Tiro General Mine by Air-Lift." Trans. Am. Inst. Mining \& Metallurgical Engrs. LXII(421-456).

Taitel, Y., D. Bornea, and A. E. Dukler. 1980. "Modelling Flow Pattern Transitions for Steady Upward Gas-Liquid Flow in Vertical Tubes." AIChE J. 26:345-354.

Towell, G. C., C. P. Strand, and G. H. Ackerman. 1965. "Mixing and Mass Transfer in Large Diameter Bubble Columns." AIChE Symp. Ser. 19.

Zenz, F. A. 1993. "Explore the Potential of Air-Lift Pumps and Multiphase." Chemical Engineering Progress August:51-56. 



\section{Distribution}

No. of

Copies

\section{OFFSITE}

Steve Gorelick

Dept. of Geological Sciences

Mitchell Building 138

Stanford University

Stanford, CA 94305-2115

Mike Pinto

Dept. of Geological Sciences

Mitchell Building 138

Stanford University

Stanford, CA 94305-2115

Gaynor Dawson

EG\&G Environmental

64209 Grover Lane

PR. N.E.

West Richland, WA 99352

Odile Francois

CEA

DANRI-SAR-SAT

17 rue des Martyrs

38056 Grenoble

France

Chris Wright

Hart-Crowser

1201 Jadwin Ave., Suite 204

Richland, WA 99352

Tom McKeon

EG\&G Environmental

16935 SE 39th Street

Bellevue, WA 98008
No. of

Copies

Eric Jensen

EG\&G Environmental

2104 Shasta Ave.

Richland, WA 99352

David Steckel

Environmental Management Office

$70 \mathrm{~N}$ Wolfe Ave. (Building 1632)

Edwards AFB, CA 93524-6225

\section{ONSITE}

21 Pacific Northwest National Laboratory

L. M. Lilgegren K7-15

C. N. Stewart K7-15

T. M. Brouns K9-08

B. N. Bjornstad K6-81

H. A. Kirwin-Taylor Seattle

C. K. Thornhill K9-14

G. R. Holdren K6-81

J. L. Devary K6-96

M. D. White K9-36

P. E. Long K9-48

G. W. Gee K9-33

T. J Gilmore (10) K6-81

Department of Energy

L. Mamiya

Bechtel Hanford Company

Steve Trent 
